\title{
Reform and amendment of Russian petroleum fiscal term: trends and implication to asset acquisition
}

\author{
Jin Zhang*, Xiuling Yin, Zuxin Li, Dufen Sun, and Shenaoyi Liu \\ Research Institute of Petroleum Exploration and Development, CNPC, No. 20, Xueyuan Road, Haidian District, \\ 100083 Beijing, China
}

Received: 15 January 2020 / Accepted: 26 May 2020

\begin{abstract}
This article analyzes reform and amendment of petroleum tax policy in Russia to investigate instability of tax regime which is one of the main concerns for decision making in asset acquisition. Historical and recent amendments of upstream fiscal terms in Russia are reviewed and studied in an attempt to understand the trends of reform. Tax burden of four different cases is modeled with the change of tax policy to analyze the effect of tax incentives. The recent "tax maneuver" of transferring export duty to Mineral Extraction Tax (MET) is studied in detail to analyze effects to upstream, refinery, and customers. Net present values of three field cases under previous tax regime and new Added Income Tax (AIT) regime are comparatively studied with cashflow modeling. The article concludes that recent "tax maneuver" has indirect influence on upstream sector but may lead to upward pressure on retail. New AIT regime introduces a universal taxation system and requires less government intervention, which may reduce aboveground risk of unstable fiscal regime and boost international investment in Russia. Also, key suggestions are summarized for international investors who are interested in oil and gas asset in Russia.
\end{abstract}

\section{Nomenclature}

$P$

Prices for Urals grade oil expressed in US dollars per barrel, which are determined as the sum of arithmetic purchase and sale prices on world crude oil markets (Mediterranean and Rotterdam) for all days of trading, divided by the number of days of trading in the relevant tax period

$R \quad$ The exchange rate of the US dollar to the Russian Federation ruble which is established by the Central Bank of the Russian Federation

$E_{\mathrm{m}} \quad$ The indicator reflecting oil extraction factors

$C_{\mathrm{p}} \quad$ The coefficient reflecting movements in world oil prices

$C_{\mathrm{d}} \quad$ The coefficient reflecting the level of depletion of reserves of a specific subsurface site

$C_{\mathrm{r}} \quad$ The coefficient reflecting the level of reserves of a specific subsurface site

$C_{\text {de }} \quad$ The coefficient reflecting the degree of difficulty of oil extraction
$C_{\text {rd }} \quad$ The coefficient reflecting hydrocarbon reservoir

$C_{\text {can }}$ The coefficient reflecting the region of extraction and properties of oil

$C_{\text {ptds }} \quad$ The increment reflecting export price of petrol and diesel fuel

$N \quad$ Cumulative oil production, million tons

$V \quad$ Initial $\mathrm{ABC} 1+\mathrm{C} 2$ recoverable reserve, million tons

$D \quad$ Export duty rate effective in the tax period

$C_{\text {man }} \quad$ The coefficient applied to move MET to export duty

$C_{\mathrm{vo}} \quad$ The coefficient reflects extraction of super viscous oil

\section{Introduction}

Russia produced 11201 thousand barrels per day of crude oil and condensate and 64.8 Bcf per day of gas in 2018 . It is one of the top oil producers in the world, alongside Saudi Arabia and the US. It holds the world's largest volume of gas reserves and is the second largest gas producer globally, behind the US [1]. There is no doubt that

\footnotetext{
* Corresponding author: zhangjincup@163.com
} 
Russia is rich in oil and gas, but abundant oil and gas resources does not persuade international investors to be active in Russian upstream market. The only one big deal of acquisition recently is NOVATEK's Arctic LNG-2 in 2019.

Compared to other countries, oil and gas industry in Russia faces internal and external challenges such as sanction imposed by the US and EU [2,3]. Also, unstable fiscal term might be one of the main concerns for decision making in asset acquisition. Some papers studied the tax regime of oil and gas industry in Russia. Alexeev and Conrad analyzed government took under the tax policy of Russia in 2008 and compared with tax regime in other countries such as Australia and Canada [4]. Fjaertoft and Lunden analyzed the policy of "tax maneuver" introduced in 2014 with real world field study, and concluded that it is poorly evaluated in terms of simplicity, flexibility, stability, and competitiveness [5]. Filimonova et al. conducted cluster analysis on tax burden of Mineral Extraction Tax (MET) and export duty from 2010 to 2017 and proposed suggestions for petroleum tax reform in Russia [6].

Recently, the Russian government reforms the tax regime again, gradually moves export duty to MET and introduces Added Income Tax (AIT). The objective of this article is trying to understand the challenges to international investors in perspective of unstable fiscal regime. The history of Russian petroleum tax policy is reviewed and analyzed with case and scenario study. Challenges and advantages of recent reform and tax code adjustment are studied.

\section{Current petroleum tax regime in Russia}

For cooperation of petroleum extraction in the world, the main fiscal regime could be divided as royalty and tax concession, Production Sharing Contract (PSC), and service contract. Except the only three operating PSCs in Russia, which are Sakhalin-1, Sakhalin-2, and Kharyaginskoye, nearly all of the oil and gas assets apply to royalty and tax concession. And this is the main tax regime discussed in this article.

The tax regime of concession in Russia is shown in Figure 1. For upstream oil and gas in Russia, most of the tax burden comes from gross taxes like Mineral extraction tax and export duty. Other taxes like $2.2 \%$ of property tax and $20 \%$ of profit tax are relatively stable, and some specific companies or assets such as arctic LNG project might benefit from incentives. Mineral extraction tax and export duty are gross tax, which is easy to monitor and collect but insensitive to costs and quickly distort investment decisions. Export duty is easy to administer, but leads to foreign/domestic price wedges and also insensitive to costs [5]. Smith divided the tax regime into frontend loaded tax regimes and back-end loaded tax systems [7]. Obviously, Russia becomes an impatient and risk-averse country which prefers frontend loaded tax regime and collect tax revenue through gross tax. The reason of being impatient and risk-averse may be that nearly $40-50 \%$ of government revenue relies on oil and gas industry [8].

\subsection{Mineral extraction tax}

According to the Tax Code updated in December 25th of 2018 [9], the calculation of MET is shown as following:

$$
\operatorname{MET}(\mathrm{rub} / \text { ton })=\operatorname{MET} \text { Rate } \times C_{\mathrm{p}}-E_{\mathrm{m}} .
$$

MET rate is set as $919 \mathrm{rub} /$ ton from 2017.

$$
C_{\mathrm{p}}=(P-15) \times R / 261
$$

The indicator reflecting oil extraction factors $\left(E_{\mathrm{m}}\right)$ is calculated with equation (3):

$$
\begin{aligned}
E_{\mathrm{m}}= & C_{\mathrm{met}} \times C_{\mathrm{p}} \times\left(1-C_{\mathrm{d}} \times C_{\mathrm{r}} \times C_{\mathrm{de}} \times C_{\mathrm{rd}} \times C_{\mathrm{can}}\right) \\
& -C_{\mathrm{c}}-C_{\mathrm{ptds}}-C_{\mathrm{man}} \times C_{\mathrm{vo}} .
\end{aligned}
$$

$C_{\text {met }}$ is set as $559 \mathrm{rub} /$ ton from 2017 , and $C_{\mathrm{c}}$ is set as 357 in 2018 inclusively, and 428 for the period from 2019 to 2021.

$C_{\mathrm{d}}, C_{\mathrm{r}}, C_{\mathrm{de}}, C_{\mathrm{rd}}$, and $C_{\text {can }}$ are five different coefficients for tax incentive, as shown in Table 1 . The objective of these coefficients is to stimulate investment and maintain production. For brown fields that depletion rate higher than $80 \%$, MET is reduced. And the depletion rate defined here is not consistent with the terminology in reservoir engineering, it equals the ratio of cumulative production and initial booked recoverable reserve, and probably higher than $100 \%$. For scenario of recoverable reserve less than 5 million tons, low permeability and thin net pay, viscosity higher than $200 \mathrm{mPa}$ s and field locates in specific region, the government reduces MET and encourages to invest in those fields with difficulty and high cost.

The coefficient $C_{\text {ptds }}$ was introduced in 2018 and comes into effect from January 1st of 2019:

$$
C_{\mathrm{ptds}}=N_{\mathrm{pt}} \times I_{\mathrm{pt}}+N_{\mathrm{ds}} \times I_{\mathrm{ds}},
$$

where $N_{\mathrm{pt}}$ is a coefficient reflecting an increment for petrol and equals 125 for tax periods of 2019 inclusively, and 105 for tax periods commencing after January 1st of 2020. $N_{\mathrm{ds}}$ is a coefficient reflecting an increment for diesel fuel and equals 110 for tax periods of 2019 inclusively, and 92 for tax periods commencing after January 1st of 2020.

$I_{\mathrm{pt}}$ and $I_{\mathrm{ds}}$ are binary coefficients for petrol. If the average price of the export alternative for class 5 RON 92 Petrol or class 5 diesel fuel is higher than the notional value of the wholesale price in the territory of the Russian Federation, $I_{\mathrm{pt}}$ or $I_{\mathrm{ds}}$ shall equal to 1 , otherwise shall be 0 . The notional value of the wholesale price of class 5 RON 92 Petrol and class 5 diesel fuel is shown in Table 2.

$C_{\mathrm{man}}$ is the coefficient applied to move MET to export duty, and calculated with equation (5):

$$
C_{\text {man }}=\mathrm{ED} \times R \times C_{\text {adj }}-\mathrm{FM},
$$

where $C_{\text {adj }}$ is set as 0.167 in $2019,0.333$ in $2020,0.500$ in 2021, 0.667 in 2022, 0.833 in 2023 and 1 from 2024. And ED is calculated with the equation in Table 3 .

$C_{\mathrm{vo}}$ is the coefficient reflects extraction of super viscous oil, and shall be set as 0.1 in the case of viscosity not less than $10000 \mathrm{mPa} \mathrm{s}$ (under formation conditions). Otherwise, it shall be 1 . 


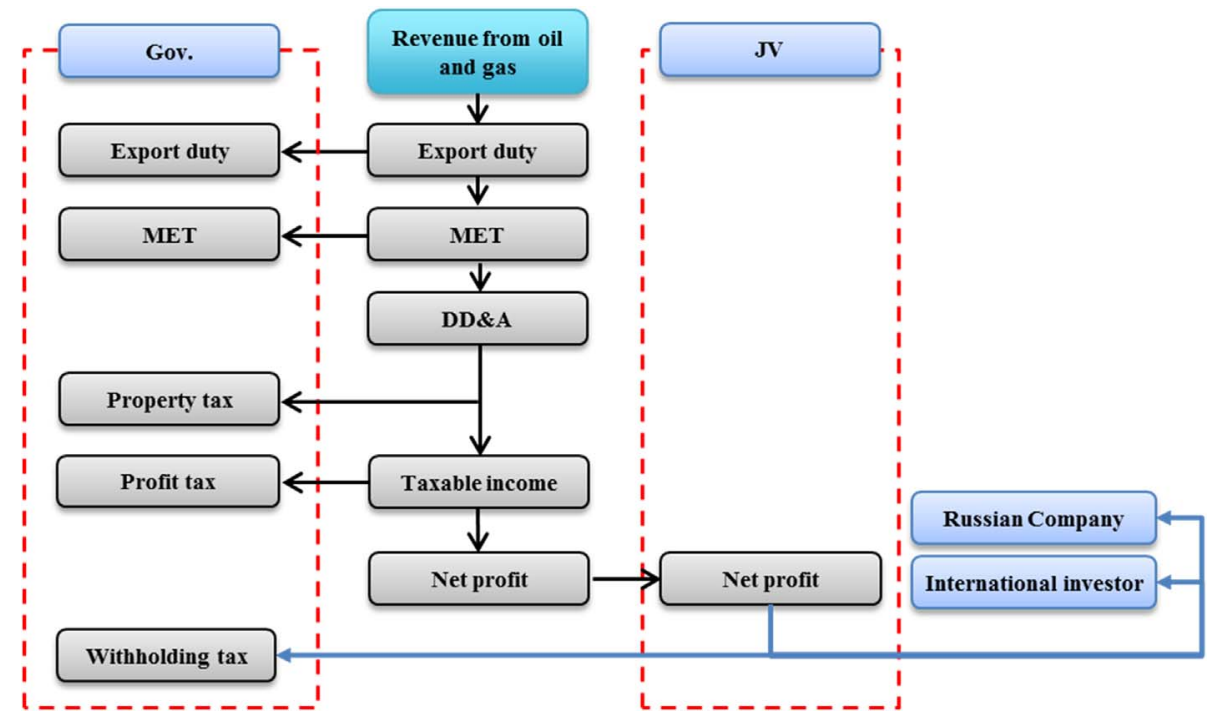

Fig. 1. Tax regime of concession in Russia.

Table 1. Coefficients for mineral extraction tax inventive.

\begin{tabular}{|c|c|c|}
\hline Coefficient & Objective & Application \\
\hline$C_{\mathrm{d}}$ & Depletion of reserves & $\begin{array}{l}1, \text { if } N / V<80 \% \\
3.8-3.5 \times N / V, \text { if } N / V \geq 80 \% \\
0.3, \text { if } N / V>100 \%\end{array}$ \\
\hline$C_{\mathrm{r}}$ & Level of reserves & $\begin{array}{l}0.125 \times V+0.375, \text { where } V \text { lower than } 5 \text { million tons and } \\
\text { depletion less than } 5 \% \\
1 \text {, others }\end{array}$ \\
\hline$C_{\mathrm{de}}$ & Degree of difficulty & $\begin{array}{l}0.2 \text {, if permeability less than } 2 \mathrm{mD} \text { and net pay less than } 10 \mathrm{~m} \\
0.4 \text {, if permeability less than } 2 \mathrm{mD} \text { and net pay more than } 10 \mathrm{~m} \\
0.8 \text {, Tyumen formation } \\
1 \text {, others }\end{array}$ \\
\hline$C_{\mathrm{rd}}$ & Hydrocarbon reservoir & $\begin{array}{l}1, \text { if } C_{\mathrm{de}}<1, N / V<0.8 \text { for a reservoir } \\
3.8-3.5 \times N / V \text {, if } C_{\mathrm{de}}<1,0.8 \leq N / V \leq 1 \\
0.3, \text { if } C_{\mathrm{de}}<1, N / V>1 \\
C_{\mathrm{de}}, \text { if a reservoir with } C_{\mathrm{de}}=1 \text { and there are other reservoirs at the field } \\
\text { with } C_{\mathrm{de}}<1\end{array}$ \\
\hline$C_{\text {can }}$ & $\begin{array}{l}\text { Region of extraction and } \\
\text { properties of oil }\end{array}$ & $\begin{array}{l}0 \text {, if viscosity greater than } 200 \mathrm{mPa} \text { s and less than } 10000 \mathrm{mPa} s \\
\text { (under formation condition) } \\
0 \text {, for specified period of time or until cumulative production reaches } \\
\text { a threshold (whichever occurs first), if oil produced from fields that } \\
\text { lie wholly or partially in specified regions } \\
1 \text {, others }\end{array}$ \\
\hline
\end{tabular}

Table 2. Notional wholesale fuel price in Russia.

\begin{tabular}{lcc}
\hline & $\begin{array}{c}\text { Class 5 RON 92 Petrol notional } \\
\text { wholesale price, rub/ton }\end{array}$ & $\begin{array}{c}\text { Class } 5 \text { diesel fuel notional } \\
\text { wholesale price, rub/ton }\end{array}$ \\
\hline 2019 & 56000 & 50000 \\
2020 & 58800 & 52500 \\
2021 & 61740 & 55125 \\
\hline
\end{tabular}


Table 3. Calculation of ED.

\begin{tabular}{lc}
\hline Urals crude oil price (Mediterranean and Rotterdam) & ED \\
\hline Less than 109.5 USD/ton & 0 \\
$109.5-146$ USD/ton & (Urals -109.5$) \times 35 \%$ \\
$146-182.5$ USD/ton & (Urals -146$) \times 45 \%+12.78$ \\
More than 182.5 USD/ton & (Urals -182.5$) \times 30 \%+29.2$ \\
\hline
\end{tabular}

The coefficient FM reflecting the occurrence of special circumstances shall be taken to be equal to zero for all tax periods by default. If clause 6.2 of Article 3.1 of the Law of the Russian Federation "Concerning the Customs Tariff" is put into effect, FM shall be calculated with equation (6), where $D$ is export duty rate effective in the tax period.

$$
\mathrm{FM}=\left(D-\mathrm{ED} \times\left(1-C_{\mathrm{adj}}\right)\right) \times R
$$

\subsection{Current export duty}

According to the Export Duty of the Russian Federation [10] in July 19th of 2018, the general formula of oil export duty for Urals price not less than 25 USD per barrel is shown below:

$$
D=(29.2+(\text { Urals }-182.5) \times 30 \%) \times\left(1-C_{\text {adj }}\right) .
$$

The coefficient of $C_{\mathrm{adj}}$ defined here is the same in equation (5). It gradually moves equivalent tax rate from export duty to MET, even though the tax bases of MET and export duty are slightly different. For the case of Urals price less than 25 USD per barrel (182.5 USD per ton), the formula of unadjusted export duty stays the same with Table 3.

The law also establishes special formulas regarding to super viscous oil and other blocks with difficulty. For oil with viscosity more than $10000 \mathrm{mPa}$ s, the formula with tax incentive is set as:

$$
D=0.1 \times(29.2+(\text { Urals }-182.5) \times 30 \%) \times\left(1-C_{\text {adj }}\right) \text {. }
$$

For oil extracted at the blocks named in the Law "On Customs Tariff" (subitems 2 and 3 of item 5 of Article 3.1 of the Law), the formula with tax incentive is set as:

$$
\begin{aligned}
D(\text { not less than } 0)= & (\text { Urals }-182.5) \times 30 \%-56.57 \\
& - \text { Urals } \times 0.14 .
\end{aligned}
$$

At the same time, a "barrage" duty mechanism is introduced to increase duties on oil and oil products in the case that Urals price increase more than $15 \%$ in ruble per ton compared to the average price of 3 consecutive periods preceding the currently monitored period. And it shall be calculated as:

$$
D=29.2+(\text { Urals }-182.5) \times 45 \% .
$$

And the "barrage" duties can be established for the period not more than 6 months.

\section{History tax amendments}

The petroleum fiscal terms have been revised and amended for numerous times since introduction following the ending of Soviet Union. In the 1990s, the tax regime was fieldspecific and it was difficult to monitor cost at that special period. Reporting high cost was used by companies to reduce taxable profit, which leads tax revenue loss for government [11]. In the early 2000s, the government started to reform the tax regime and move the main tax burden to gross tax like MET and export duty. Other tax like profit tax and property tax was reserved from the old tax system [12]. Even though the government keeps amending the tax code every year, the current tax structure is still in line with it. With the reform of tax regime, the government received higher tax revenue, but it inevitably impeded the investment in oil and gas field with high cost. To stimulate production, various of incentives were introduced and became increasingly unstable and complicated.

The above described formula of MET and export duty at end of 2018 is very complicated with lots of special incentives and increment coefficient, rather than a fixed rate in other country. It has been amended and developed based on the simple tax structure in the early 2000s. The detailed amendments and developments of MET for crude oil since 2002 are listed in Appendix Table A1 [8].

The effective MET rate is defined as ratio of MET and Urals Price in this paper. It changes automatically depending on Urals oil price with equation of MET defined in equation (1). Figure 2 shows the history change of effective MET rate, and the effect here is a comprehensive result of automatic adjustments and government amendments. From 2002 to 2008, the effective MET rate has been gradually increased with the increase of oil price. For the regular base case, the effective MET rate is increased from $12.7 \%$ to $20.3 \%$. With the collapse of international oil price in 2009 , the federal government increases base Urals price to 15 USD per barrel in the MET formula which results in the effective MET rate reduced to $17.0 \%$. However, when oil price recovers and bounces back, the effective MET rate gradually increases again. In 2014 and 2015, the oil price falls rapidly, but the federal government does not use the previous tactic. Contrary to previous adjustments, the MET rate is greatly increased and the percentage hit a new high of $38.8 \%$ in 2018 . To balance the tax burden, the tax rate of export duty is greatly reduced as shown in Table 4.

Figure 3 shows the combined effect of MET and export duty for regular base case from 2011 to 2018. The effective tax rate of combined MET and export duty fluctuates with oil price and has great correlation with each other. In 2016, 


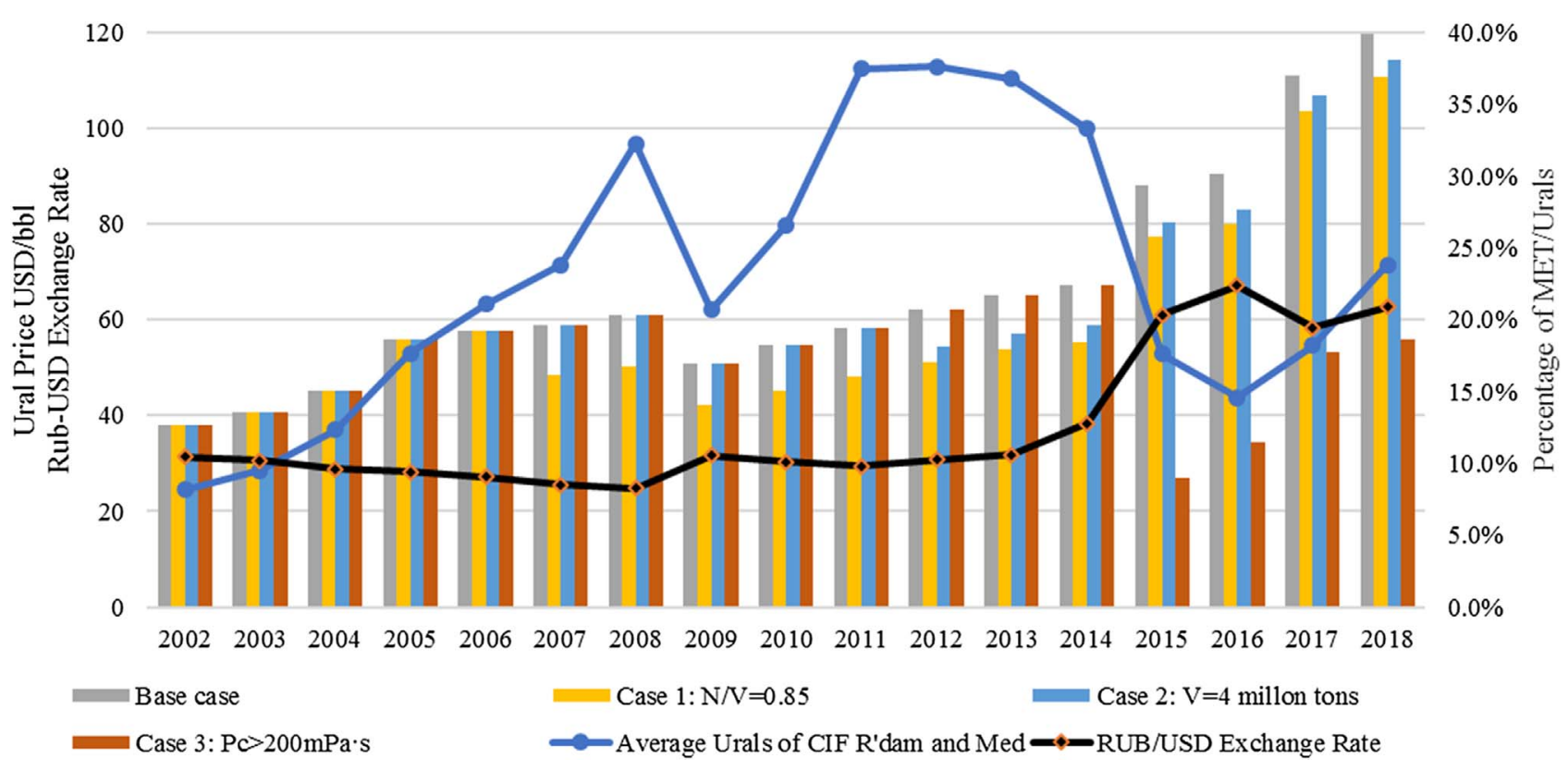

Fig. 2. History amendments of MET with fluctuation of oil price and exchange rate.

Table 4. History tax rate of export duty for Urals above 25 USD per barrel.

\begin{tabular}{lcccccccc}
\hline & 2011 & 2012 & 2013 & 2014 & 2015 & 2016 & 2017 & 2018 \\
\hline Tax Rate & $60 \%$ & $60 \%$ & $60 \%$ & $59 \%$ & $42 \%$ & $42 \%$ & $30 \%$ & $30 \%$ \\
Formula & & & ED $=29.2+($ Urals -182.5$) \times$ Tax Rate & & \\
\hline
\end{tabular}

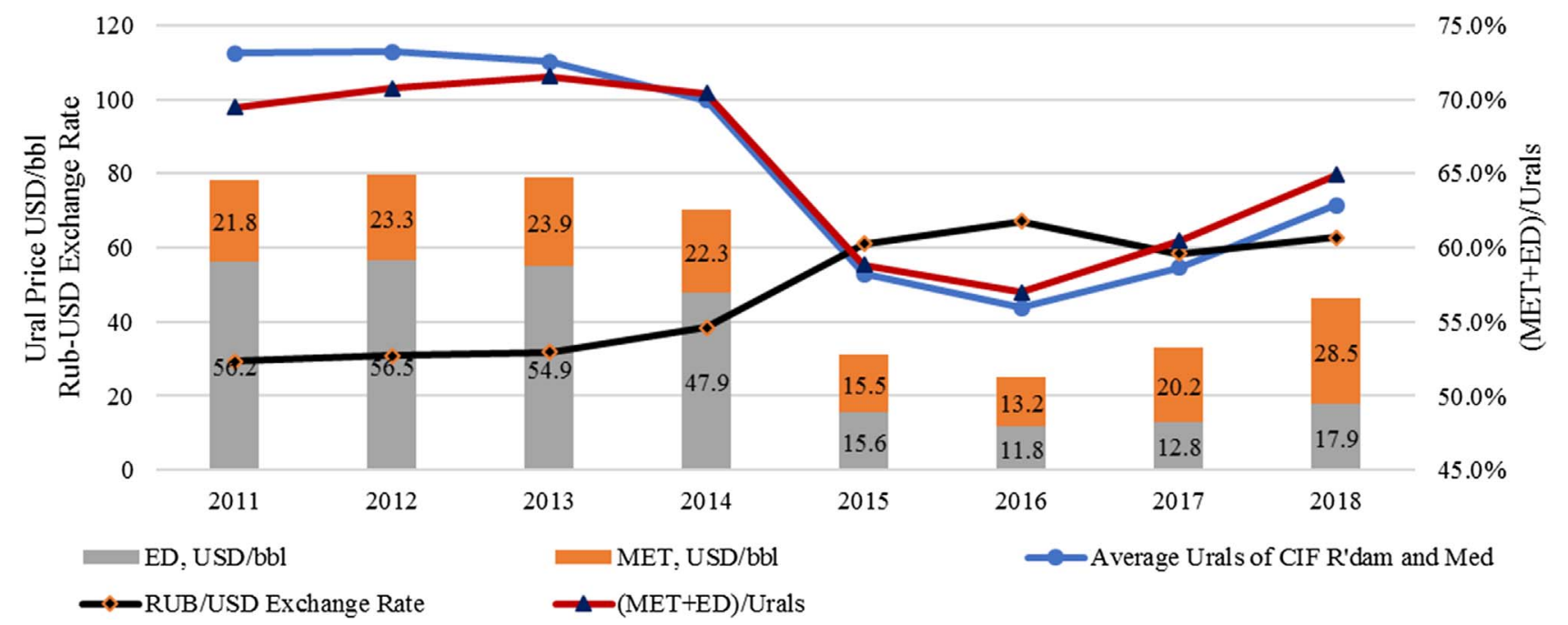

Fig. 3. History amendments of MET and export duty.

when Urals price drops down to 43.7 USD per barrel, the combined effective tax rate also reaches the new low of $57.0 \%$, which would definitely ease the pain from revenue shrinkage for crude oil producers. While in 2013 when Urals price reaches 112.8 USD per barrel, the combined effective tax rate is also very high and up to $71.5 \%$. Besides the automatic adjustment to oil price in tax equation, the federal government adjusts the main gross tax either MET or export duty, which results in higher tax burden when oil price gets higher and lower tax burden when oil price gets lower. For valuation modeling of oil and gas assets with the fixed updated tax regime, oil price would not be that sensitive as simulated in the model. Figure 4 shows the positive linear correlation between combined effective tax rate 


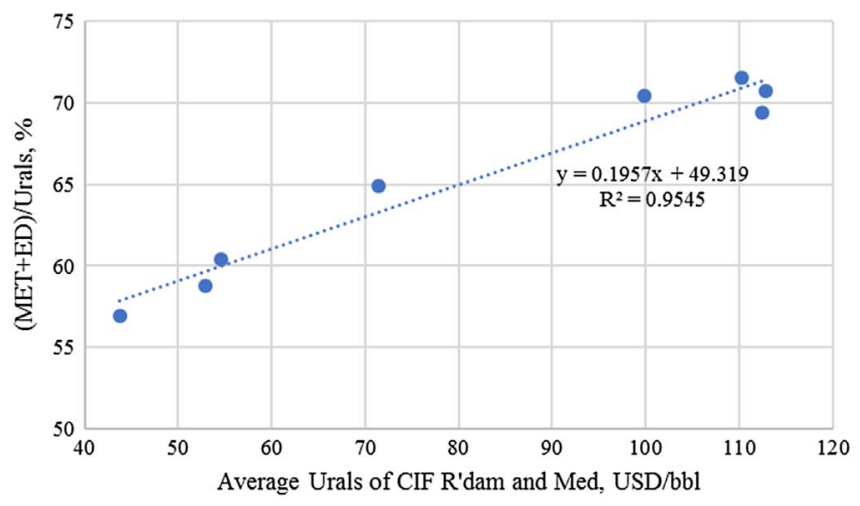

Fig. 4. Correlation of combined effective tax rate and Urals price.

and Urals price with the data of regular case from 2011 to 2018. The fitting formula is shown below:

$$
\text { Combined tax rate }(\%)=0.1957 \times \text { Urals }+49.319 \text {. }
$$

Even though export duty only applies to crude oil being exported, bidding and selling of crude oil in domestic market usually linked to export prices like Argus Urals FIP West Siberia which lead to equivalent netback price in both markets. In this way, the correlation formula in equation (11) is applicable for crude oil sold in export and domestic market.

Turning back to Figure 2, it shows the history development of tax incentives in MET. From 2007, the government introduces different kinds of incentives for some specific fields. To take MET in 2012 for example, the base regular case shall be $20.7 \%$ of effective MET rate, and the case with 0.85 of depletion rate shall be reduced to $17.1 \%$, the case with 4 million tons of initial recoverable reserve shall be reduced to $18.1 \%$. These tax incentives stimulate investment and production in brown fields and those with relatively small reserves, but the unparalleled tax break for fields with viscosity higher than $200 \mathrm{mPa}$ s is even more attractive. In 2015, the effective MET rate of base case is $29.3 \%$, and it is only $9.0 \%$ for the case with viscosity higher than $200 \mathrm{mPa}$ s. Note that the heavy oil here is conventional heavy oil with viscosity between 200 and $10000 \mathrm{mPa}$. Urals price on world crude oil markets (Mediterranean and Rotterdam) is referenced for MET and export duty for all scenarios including the case with viscosity higher than $200 \mathrm{mPa}$ s. Also, there is no quality adjustment and price discount for crude oil sold in pipeline currently in Russia. Once injected into pipeline and mixed with other crude oil, the netback price will be linked to the mixed price like Urals, ESPO, and West Siberia Light. Selling heavy oil by railway and tank truck with price discount is not the main scenario discussed here.

Tax break or incentives are certainly good news for operators, it reduces tax burden and improve profitability. However, the asset buyers should stay clear the instability of tax code in Russia, and the asset with great tax incentives are always more exposed in fiscal regime risk. Asset evaluation and price negotiation is always based on current updated tax regime, but the buyer might lose a great part of value once the government cancels the huge tax break like in the case of viscosity higher than $200 \mathrm{mPa}$.

\section{Transferring export duty to MET}

From January 1st of 2019, export duty is gradually transferred to MET, which is the so called "tax maneuver". As shown in equations (5) and (7), it moves equivalent tax rate from export duty to MET, and the export duty will be reduced to zero by 2024. $C_{\text {adj }}$ in equation (5) is the gradually ascending transferring percentage from export duty, which is $16.7 \%$ in 2019 .

Even though the bill is signed in August of 2018, this kind of "tax maneuver" reform actually starts from 2015. As shown in Table 4 and Table A1, the MET is improved with annual increase of MET rate, and export duty is reduced with adjustment of tax rate. The planned reduction of the crude oil export duty is frozen between 2017 and 2018 due to the dramatic fall in refinery margins with low oil price.

Export duty leads to foreign and domestic price wedges, and the lower price in domestic market benefits the refinery sector and consumers. Argus Urals FIP West Siberia is a very important benchmark for crude oil traded in domestic market, and the contractual price formula is usually linked to it with premium or discount. As shown in Figure 5, apart from the transportation cost, Argus Urals FIP West Siberia is 12.7 USD per barrel less than Urals traded in Mediterranean and Rotterdam in March of 2019, and the price wedge here is export duty.

However, the mechanism of "tax maneuver" is reducing export duty to zero and eliminating this foreign and domestic price wedge. Currently about $40 \%$ of crude oil in Russia is exported, which means only $40 \%$ of crude oil is levied on export duty. But by 2024, all export duty is equivalently moved to MET, so total tax burden is increased.

Who will pay for this extra tax? The simple logic is that oil producers will pass the increase in total MET payment to refineries, and refineries will pass this extra tax burden to retail sector, and finally the customers will pay for the increase. But the real situation is much more complicated.

For upstream oil producer, cashflow will be roughly stable as the sales price to domestic refineries will increase even though MET is increasing. The minor difference is that a coefficient of 0.75 is multiplied to transferred export duty for condensate, and additional MET in equation (4) is introduced when wholesale price of petrol and diesel fuel exceeds the target price in Table 2. The "tax maneuver" has little influence on netback price of crude oil for exporting because it is linked to international oil price. For the other about $60 \%$ of crude oil sold in domestic market, the situation may change. Argus Urals FIP West Siberia is usually benchmarked with premium or discount in monthly bidding of crude oil sold to domestic refinery. If the government carefully controls retail end price for political purpose, the profit margin of domestic refinery will fall. In this situation, the refinery cannot offer high premium, and it may indirectly decrease the revenue and profit of upstream company. Small independent producers who mainly focus on 


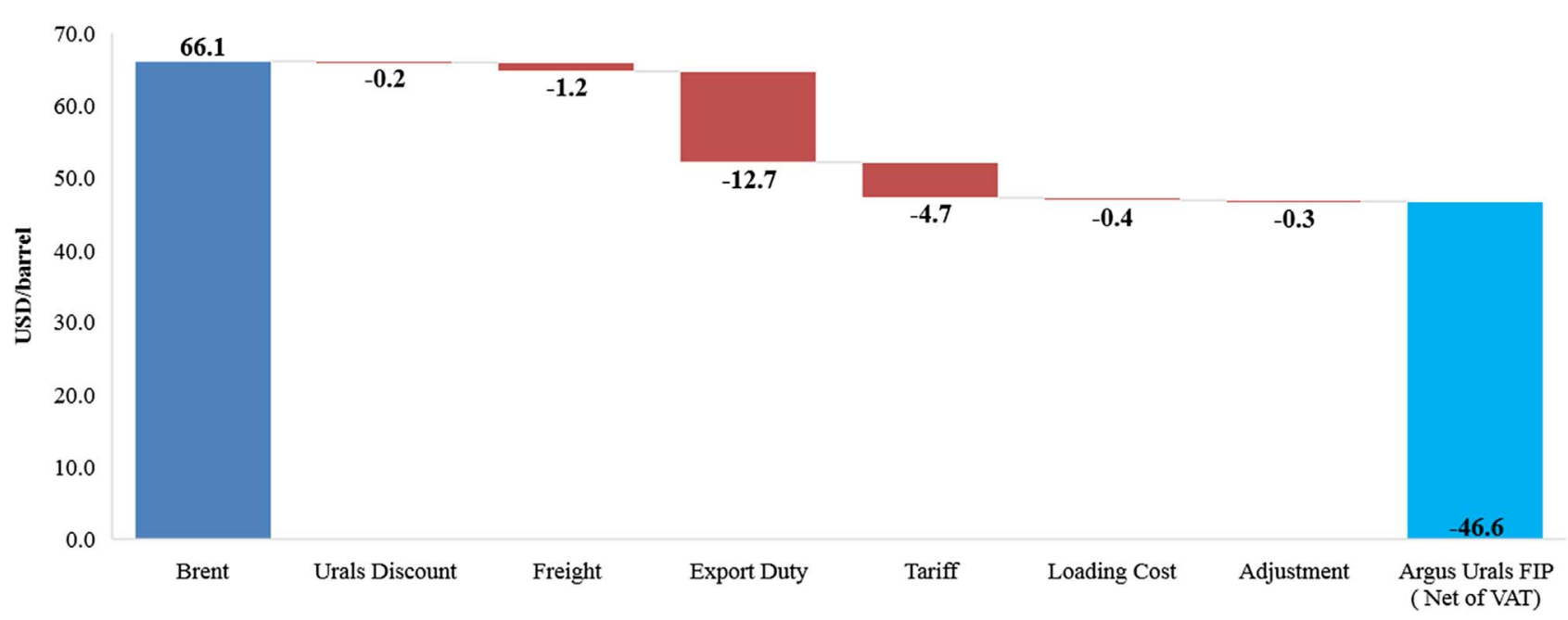

Fig. 5. Formula based Argus Urals FIP West Siberia (March of 2019).

domestic market may take losses and need to optimize the sales strategy and use the best of export quotas. There is an example of a small independent producer in Russia. The average premium to Argus Urals FIP West Siberia drops to 846 Ruble per ton in first half year of 2019 , while the average premium is 1194 Ruble per ton in 2018. The price gap of 348 Ruble per ton may result from this indirect influence. But it also may result from the oil pollution issue from April of 2019, so we still need to keep observing the influence to small independent producers. Generally, it has indirect influence on upstream sector, but small independent producers may bear more losses.

For refinery sector, the story is more complicated. The existing "custom's duty subsidy" covers the difference in export duty for crude oil and oil products. Refineries purchase crude oil at the domestic netback price close to Argus Urals FIP West Siberia, and sell oil products at domestic price or export them. The export duty for oil products such as gasoline and diesel are much less than crude oil export duty, which is only $30 \%$ of that. With benefit of this "custom's duty subsidy" to refinery sector, the oil companies are encouraged to process crude oil domestically rather than exporting it. But it ends with the implementation of "tax maneuver" after 2024. The new subsidy "reverse excise on oil" is introduced to remedy the profit margin of refinery sector and stimulate deep refining. Those refineries who supply EURO 5 gasoline and diesel to the domestic market and Russian companies under EU/US sanctions are applicable to this benefit, which accounts for $90 \%$ of the refinery sector. To support refineries in remote location, a regional uplift coefficient is regulated to amplify reverse excise which varies from 1.05 to 1.50 . Under this situation, small independent refineries with mainly heavy products are facing huge pressure with ending of "custom's duty subsidy" and non-applicable "reverse excise on oil".

As shown in Figure 6 and according to the estimates of Wood Mackenzie, the "tax maneuver" would increase 112 billion USD of MET from 2019 to 2024, and the government budget revenue would increase over $15 \%$ from it. Then, the government returns about $60 \%$ of tax increase to domestic refinery with "reverse excise on oil", and still gains compared to the previous tax regime. With extra tax in total, there would be upward pressure in retail of oil products, but this political sensitive issue should be carefully and smoothly dealt by the government.

\section{Profit based AIT regime}

In July of 2018, the AIT was passed in the State Duma of Russian Federation and was signed by V.V. Putin. The new AIT regime becomes effective from 2019 for fields meeting specific criteria which mainly green fields and about $5 \%$ of existing brown fields as shown in Table A2. The reform creates economic incentives for brown fields facing challenge of production decline and green fields with low profitability which requires high capital expenditure. According to the law, it is voluntary for this part of the fields to transfer from the original MET regime to AIT regime. Once the AIT regime is activated by notification, there is no option to switch back to the MET taxation regime.

AIT is calculated as:

$$
\mathrm{AIT}=(\text { Estimated revenue }- \text { Expenses }) \times 50 \% .
$$

Estimated revenue and expenses defined here are shown in Table 5. In case of selling gas to a third party, gas price here is contractual netback price. Gas production is net production after deduction of injection, and volume of associated gas is taken as $95 \%$ of its production. Estimated transport expense is the cost of transporting oil from the field to the world oil markets. Unused tax losses of previous tax periods are increased at a rate of $16.3 \%$ per annum in AIT tax regime. In addition, the amount of AIT tax cannot be less than the amount of minimum tax scenario with 7140 rubles per ton of unit CAPEX and OPEX from 2019 to 2020 and 9520 rubles per ton in subsequent periods.

Different from equation (1) in MET regime, the MET is reduced in the AIT regime. 


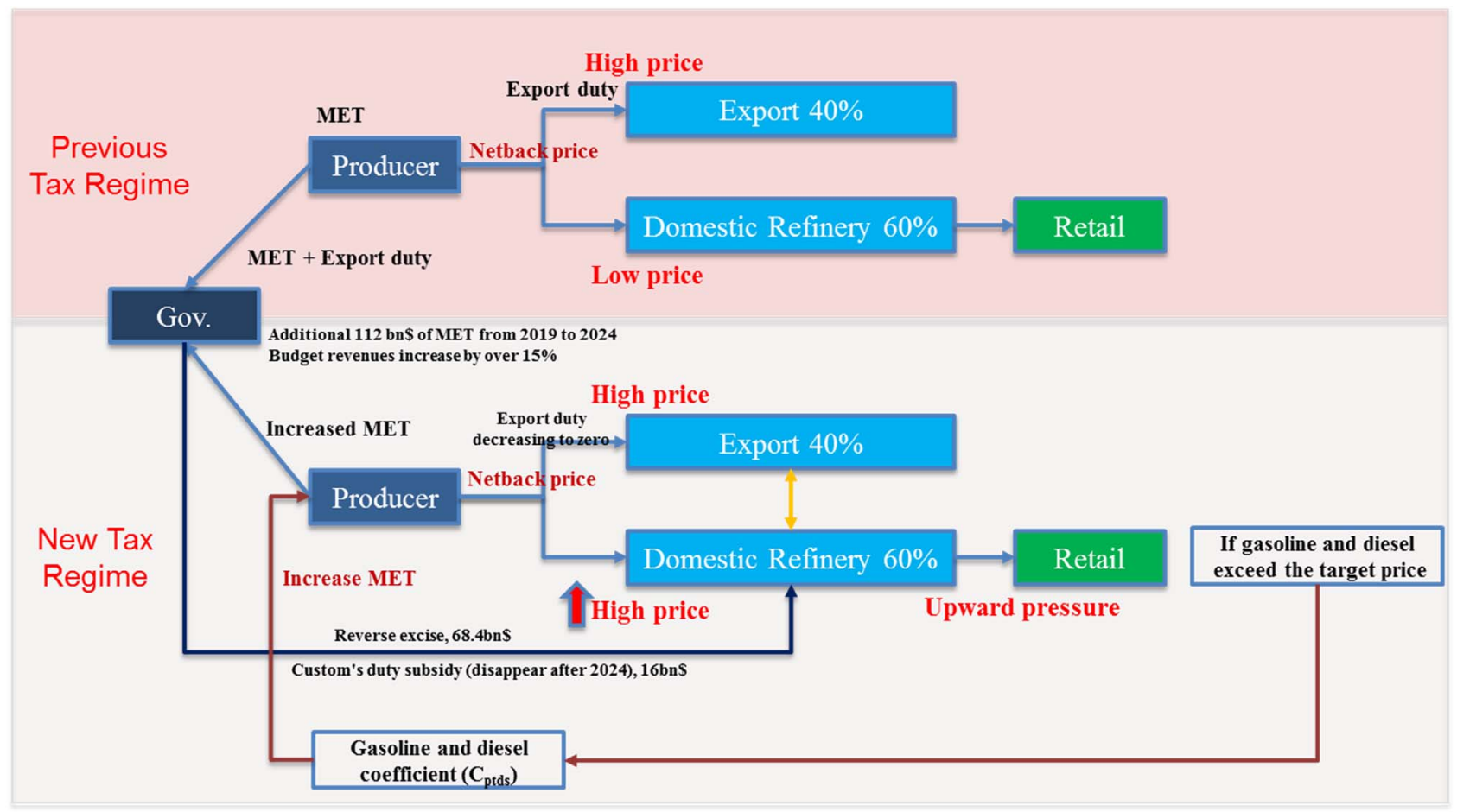

Fig. 6. Effects of "tax maneuver" to upstream and refinery sector.

Table 5. Definition in AIT formula.

Estimated revenue

Expenses
Urals Price $\times$ Oil and Condensate Production + Gas Price $\times$ Gas Production OPEX + CAPEX + Estimated Transport Expenses + MET, Property Tax, Other Taxes + Estimated Export Duty + Losses of Previous Years

Table 6. Characteristics of fields selected.

\begin{tabular}{lccr}
\hline & Field A & Field B & Field C \\
\hline Production Plateau, million ton per year & 2.1 & 4.8 & 4.5 \\
Plateau Year & $2023-2026$ & $2022-2029$ & $2017-2023$ \\
MET Exemption & Yes & No & No \\
Acc. Production since 2019, million ton & 45.0 & 94.5 & 35.9 \\
CAPEX, MMUSD & 1129 & 3713 & 1442 \\
NPV10 with MET regime, MMUSD & 2138 & 3238 & 2837 \\
NPV10 with AIT regime, MMUSD & 2103 & 5798 & 3201 \\
\hline
\end{tabular}

$$
\begin{aligned}
\operatorname{MET}(\mathrm{rub} / \text { ton })= & (P \times 7.3-109.5) \times 0.5 \times K \\
& \times R-\mathrm{ED} \times R
\end{aligned}
$$

ED is the export duty described in Section 2.2, and $K$ defined here is a privilege coefficient. For groups 1 and 2 in Table A2, $K$ is set as 0.4 before the expiration of the first 5 years of commercial production, 0.6 in 6 th year, 0.8 in 7 th year and 1.0 since 8 th year. For group $4, K$ is set as 0.5 in the first year of commercial production, 0.75 in 2 nd year, 1.0 since $3 r d$ year.
To analyze the effect of transferring tax regime to AIT, three oil fields are modeled and compared as shown in Table 6. Oil price, exchange rate and inflation are assumed according to Wood Mackenzie, and economic date is set as January 1st of 2019. The Field A is neutral to optional tax regime switching, because it already benefits from MET exemption. The Field B nearly doubled value after switching to AIT, which requires high capital expenditure before 2022 . The profit based AIT and reduced MET greatly improve the cashflow in next few years for Field B. The Field C is a 
producing field during plateau, and it has moderate positive effect to tax regime switching.

As described in Section 2, the main tax burden comes from MET and export duty, which are gross tax. Reducing MET and introducing a profit based AIT is great news for green fields like Field B. Tax burden is greatly reduced in early stage, and cashflow is improved. If the AIT regime proves a success, the government may extend it to all fields in West Siberia. It introduces a universal taxation system that requires no government interventions in case of changes in economic environment and accounts for projects' individual economic and operational features. This might reduce ground risk of unstable fiscal regime in Russia.

\section{Conclusion and implication}

The tax regime of upstream oil and gas industry were constantly amended by the government over the past decades. This above ground risk for international investors becomes one of the challenges to acquire Russian upstream assets. Based on the analysis of history amendments and recent reform of tax regime, the conclusions and suggestions are summarized as following:

1. The current prevailing MET tax regime keeps amending to fit for the financial situation, but this tax structure applicable for most of the fields will be in line with the tax regime reformed in early 2000s in the foreseeable future.

2. Besides the automatic adjustment to oil price in tax equation, the federal government adjusts the main gross tax either MET or export duty. For upstream assets evaluation in Russia, oil price would not be that sensitive as simulated, when modeling with current fixed tax regime. A comprehensive correlation formula is provided for further modeling study.

3. The recent adjustment of MET and export duty has indirect impact on the upstream sector, but may lead to upward pressure in retail of gasoline and diesel. Small independent producers who focus on domestic market may take losses indirectly. Small independent refineries with mainly heavy products are also facing great pressure with ending of "custom's duty subsidy" and non-applicable "reverse excise on oil".

4. The new introduced AIT tax regime is a great try to develop a universal taxation system that may require no government interventions in case of changes in economic environment and account for projects' individual economic and operational features. This might reduce above ground risk of unstable fiscal regime and boost international investment in Russia.

5. It is suggested that asset buyers should stay clear the instability of tax code in Russia, and assets with great tax incentives are always more exposed in fiscal regime risk. If asset evaluation and price negotiation are based on current fixed tax regime, buyers should consider the risk and uncertainly of canceling tax break. Inter-government agreement to ensure the stability of tax incentives might be one of the options.

Acknowledgments. This study is supported by the National Science and Technology Major Project (No. 2016 ZX05029-003).

\section{References}

1 BP Statistical Review of World Energy (2019) 68th edition. https://www.bp.com/content/dam/bp/business-sites/en/ global/corporate/pdfs/energy-economics/statistical-review/ bp-stats-review-2019-full-report.pdf.

2 Kryukov V., Moe A. (2018) Does Russian unconventional oil have a future? Energy Policy 119, 41-50.

3 Kapustin N.O., Grushevenko D.A. (2019) A long-term outlook on Russian oil industry facing internal and external challenges, Oil Gas Sci. Technol. - Rev. IFP Energies nouvelles $\mathbf{7 4}, 72$.

4 Alexeev M., Conrad R. (2009) The Russian oil tax regime: A comparative perspective, Eurasian Geogr. Econ. 50, 1, 93-114.

5 Fjaertoft D., Lunden L.P. (2015) Russian petroleum tax policy - Continuous maneuvering in rocky waters, Energy Policy 87, 553-561.

6 Filimonova I.V., Provornaya I.V., Shumilova S.I., Zemnukhova E.A. (2019) Cluster analysis of Russian oil companies based on tax burden parameters, J. Tax Reform 5, 1, 42-56.

7 Smith J.L. (2013) Issues in extractive resource taxation: A review of research methods and models, Resour. Policy 38, 3, 320-331.

8 Zhang J., Wang J., Shi J. (2019) Analysis on the effect of tax reform in Russian oil and gas industry, Int. Pet. Econ. 27, 5, 64-71 [in Chinese].

9 Tax Code of the Russian Federation (2018) Edition of December 25th. https://www.ey.com/Publication/vwLUAssets/EY-russian-tax-code-part-two-eng/\%24FILE/EY-russian-tax-code-part-two-eng.pdf.

10 Export Duty of the Russian Federation (2018) Edition of July 19th. http://www.consultant.ru/document/cons doc LAW 1995/.

11 Kryukov V., Moe A. (2007) Russia's oil industry: Risk aversion in a risk-prone environment, Eurasian Geogr. Econ. 48, 3, 341-357.

12 Lund D. (2002) Rent taxation when cost monitoring is imperfect, Resour. Energy Econ. 24, 3, 211-228. 
Table A1. History amendments of MET for crude oil.

\begin{tabular}{|c|c|c|c|c|c|c|c|c|c|c|c|}
\hline No. & Year & MET equation & $\begin{array}{l}\text { MET rate } \\
\text { (rub/ton) }\end{array}$ & $\begin{array}{l}\text { Base Urals } \\
\text { price } \\
(\mathrm{USD} / \mathrm{bbl})\end{array}$ & $C_{\mathrm{p}}$ & & $\begin{array}{l}\text { Field depletion } \\
\text { coefficient } C_{\mathrm{d}}\end{array}$ & $\begin{array}{c}\text { Reserve } \\
\text { coefficient } C_{\mathrm{r}}\end{array}$ & $C_{\text {met }}$ & $C_{\mathrm{c}}$ & $\begin{array}{l}\text { Oil extraction } \\
\text { factors } E_{\mathrm{m}}\end{array}$ \\
\hline 1 & $\begin{array}{c}2002- \\
2003\end{array}$ & MET Rate $\times C_{\mathrm{p}}$ & 340 & 8 & $\begin{array}{l}(P-8) \times \\
R / 252\end{array}$ & & - & - & - & - & - \\
\hline 2 & 2004 & MET Rate $\times C_{\mathrm{p}}$ & 347 & 8 & $\begin{array}{l}(P-8) \times \\
R / 252\end{array}$ & $\times$ & - & - & - & - & - \\
\hline 3 & $\begin{array}{l}2005- \\
2006\end{array}$ & MET Rate $\times C_{\mathrm{p}}$ & 419 & 9 & $\begin{array}{l}(P-9) \times \\
R / 261\end{array}$ & $\times$ & - & - & - & - & - \\
\hline 4 & $\begin{array}{c}2007- \\
2008\end{array}$ & $\begin{array}{l}\text { MET Rate } \times C_{\mathrm{p}} \times \\
C_{\mathrm{FD}}\end{array}$ & 419 & 9 & $\begin{array}{l}(P-9) \times \\
R / 261\end{array}$ & & $\begin{array}{l}3.8-3.5 \\
\times(N / V)\end{array}$ & - & - & - & - \\
\hline 5 & $\begin{array}{c}2009- \\
2011\end{array}$ & $\begin{array}{l}\text { MET Rate } \times C_{\mathrm{p}} \times \\
C_{\mathrm{FD}}\end{array}$ & 419 & 15 & $\begin{array}{l}(P-15) \\
R / 261\end{array}$ & $\times$ & $\begin{array}{l}3.8-3.5 \\
\times(N / V)\end{array}$ & - & - & - & - \\
\hline 6 & 2012 & $\begin{array}{l}\text { MET Rate } \times C_{\mathrm{p}} \times \\
C_{\mathrm{FD}} \times C_{\mathrm{RS}}\end{array}$ & 446 & 15 & $\begin{array}{l}(P-15) \\
R / 261\end{array}$ & $\times$ & $\begin{array}{l}3.8-3.5 \\
\times(N / V)\end{array}$ & $\begin{array}{l}0.125 \times V \\
\quad+0.375\end{array}$ & - & - & - \\
\hline 7 & 2013 & $\begin{array}{l}\text { MET Rate } \times C_{\mathrm{p}} \times \\
C_{\mathrm{FD}} \times C_{\mathrm{RS}}\end{array}$ & 470 & 15 & $\begin{array}{l}(P-15) \\
R / 261\end{array}$ & $\times$ & $\begin{array}{l}3.8-3.5 \\
\times(N / V)\end{array}$ & $\begin{array}{l}0.125 \times V \\
\quad+0.375\end{array}$ & - & - & - \\
\hline 8 & 2014 & $\begin{array}{l}\text { MET Rate } \times C_{\mathrm{p}} \times \\
C_{\mathrm{FD}} \times C_{\mathrm{RS}}\end{array}$ & 493 & 15 & $\begin{array}{l}(P-15) \\
R / 261\end{array}$ & $\times$ & $\begin{array}{l}3.8-3.5 \\
\times(N / V)\end{array}$ & $\begin{array}{l}0.125 \times V \\
\quad+0.375\end{array}$ & - & - & - \\
\hline 9 & 2015 & $\begin{array}{l}\text { MET } \\
\text { Rate } \times C_{\mathrm{p}}-E_{\mathrm{m}}\end{array}$ & 766 & 15 & $\begin{array}{l}(P-15) \\
R / 261\end{array}$ & $\times$ & $\begin{array}{l}3.8-3.5 \\
\times(N / V)\end{array}$ & $\begin{array}{l}0.125 \times V \\
+0.375\end{array}$ & 530 & - & $\begin{array}{l}C_{\text {met }} \times C_{\mathrm{p}} \times\left(1-C_{\mathrm{d}} \times C_{\mathrm{r}}\right. \\
\left.\times C_{\mathrm{de}} \times C_{\mathrm{rd}} \times C_{\mathrm{can}}\right)\end{array}$ \\
\hline 10 & 2016 & $\begin{array}{l}\text { MET } \\
\text { Rate } \times C_{\mathrm{p}}-E_{\mathrm{m}}\end{array}$ & 857 & 15 & $\begin{array}{l}(P-15) \\
R / 261\end{array}$ & $\times$ & $\begin{array}{l}3.8-3.5 \\
\times(N / V)\end{array}$ & $\begin{array}{l}0.125 \times V \\
+0.375\end{array}$ & 559 & - & $\begin{array}{l}C_{\text {met }} \times C_{\mathrm{p}} \times\left(1-C_{\mathrm{d}} \times C_{\mathrm{r}}\right. \\
\left.\times C_{\mathrm{de}} \times C_{\mathrm{rd}} \times C_{\text {can }}\right)\end{array}$ \\
\hline 11 & 2017 & $\begin{array}{l}\text { MET } \\
\text { Rate } \times C_{\mathrm{p}}-E_{\mathrm{m}}\end{array}$ & 919 & 15 & $\begin{array}{l}(P-15) \\
R / 261\end{array}$ & $\times$ & $\begin{array}{l}3.8-3.5 \\
\times(N / V)\end{array}$ & $\begin{array}{l}0.125 \times V \\
\quad+0.375\end{array}$ & 559 & 306 & $\begin{array}{l}C_{\text {met }} \times C_{\mathrm{p}} \times\left(1-C_{\mathrm{d}} \times C_{\mathrm{r}}\right. \\
\left.\times C_{\mathrm{de}} \times C_{\mathrm{rd}} \times C_{\mathrm{can}}\right)-C_{\mathrm{c}}\end{array}$ \\
\hline 12 & 2018 & $\begin{array}{l}\text { MET } \\
\text { Rate } \times C_{\mathrm{p}}-E_{\mathrm{m}}\end{array}$ & 919 & 15 & $\begin{array}{l}(P-15) \\
R / 261\end{array}$ & $\times$ & $\begin{array}{l}3.8-3.5 \\
\times(N / V)\end{array}$ & $\begin{array}{l}0.125 \times V \\
+0.375\end{array}$ & 559 & 357 & $\begin{array}{l}C_{\text {met }} \times C_{\mathrm{p}} \times\left(1-C_{\mathrm{d}} \times C_{\mathrm{r}}\right. \\
\left.\times C_{\mathrm{de}} \times C_{\mathrm{rd}} \times C_{\mathrm{can}}\right)-C_{\mathrm{c}} \\
-C_{\mathrm{man}} \times C_{\mathrm{vo}}\end{array}$ \\
\hline 13 & 2019 & $\begin{array}{l}\text { MET } \\
\text { Rate } \times C_{\mathrm{p}}-E_{\mathrm{m}}\end{array}$ & 919 & 15 & $\begin{array}{l}(P-15) \\
R / 261\end{array}$ & $\times$ & $\begin{array}{l}3.8-3.5 \\
\times(N / V)\end{array}$ & $\begin{array}{l}0.125 \times V \\
+0.375\end{array}$ & 559 & 428 & $\begin{array}{l}C_{\mathrm{met}} \times C_{\mathrm{p}} \times\left(1-C_{\mathrm{d}} \times C_{\mathrm{r}} \times\right. \\
\left.C_{\mathrm{de}} \times C_{\mathrm{rd}} \times C_{\mathrm{can}}\right)-C_{\mathrm{c}} \\
-C_{\mathrm{ptds}}-C_{\mathrm{man}} \times C_{\mathrm{vo}}\end{array}$ \\
\hline
\end{tabular}


Table A2. Criteria of AIT regime.

\begin{tabular}{lcc}
\hline Group & Location & Depletion of reserves on \\
01.01 .2017 & Additional terms
\end{tabular}

1 The Republic of Sakha (Yakutia)

Irkutsk region

Krasnoyarsk region

NAO

YaNAO (north of $65^{\circ}$ of

latitude)

Caspian Sea

2 The fields specified in Note 8 in common customs tariff of

Eurasian Economic Union on 01.01 .2018

3

Tyumen region

KhMAO

YaNAO

The Republic of Komi

4

Tyumen region $\quad K \leq 5 \%$
KhMAO
YaNAO
The Republic of Komi

1) $K \leq 5 \%$

2) Initial reserve booking later than 01.01.2017
Automatic application to apply AIT regime with single right of refusal (notice due by 31.03 .2019 )

Optional transition to AIT regime before 01.01.2020

1) $20 \% \leq N / V \leq 80 \%$

2) $10 \% \leq N / V \leq 80 \%$ and $N / V>1 \%$ on 01.01 .2011

$K \leq 5 \%$
Pilot projects as a result of requests from subsoil users with production of crude oil and condensate in 2016 less than 15 million tons

Pilot projects as a result of requests from subsoil users with initial recoverable crude oil reserves on 01.01.2017 not more than 10 million tons and initial recoverable crude oil and condensate total reserves on 01.01.2017 not more than 51 million tons 